\title{
Male Chauvinism in Afghan Society: An Analysis of $A$ Thousand Splendid Suns
}

\author{
* Dr. Waheed Ahmad Khan, Ass sistant Profess or (Corres ponding Author) \\ ** Dr. Shaukat Ali, Assistant Professor \\ *** Mr. Gul Zamin Khan, Assistant Professor
}

\begin{abstract}
The paper is an attempt to analyze the dominant role of the male community in Afghan society. Western Feminists such as Judith Butler claim that all women face the same problems. However, their claim is challenged by Chandra Talpade Mohanty (1991) who is of the view that the claim of universal sisterhood is based on ethnocentricity. This paper analyses the inferior status of women in the patriarchal system of Afghanistan where people live under their cultural code called Pashtunwali. Pashtunwali assigns an active role to the male community under their privileged status while women are restricted to homes. In this society, a man has to be rigid, authoritative and must keep women under his iron hands. A man of weak nerves has no respect in Afghan society; he has to be strong enough to protect the honor of his family. The study is based on textual analysis of Khaled Hosseini's novel, A Thousand Splendid Suns, in the light of Mohanty's views (1991). Hosse ini (2008) criticizes the marginalized status of women in Afghan society. Though the Afghan society is influenced by globalization which gives some space to women for social activities, male chauvinism remains the main feature of Pashtun culture wherein people are ruled by a male-oriented code of conduct called Pashtunwali.
\end{abstract}

Keywords: Male Chauvinism, Patriarchy, Nang, Namoos, Marginalisation, Pashtunwali Introduction

Western feminism has highlighted issues of women in male-dominated societies. Previously it was believed that the difference between men and women was a matter of biological differences. This approach is called biological determinism (Morton, 2003, pp. 86-87). It supported the monolithic status of women whose identity was constructed on the belief "in the inborn inferiority of women" (Tyson, 2006, p. 85). Simone de Beauvoir, the French feminist, challenged the claim of gender identity which was determined by biological sex (Morton, 2003, p. 73). According to this claim, the identity of women is a matter of social construction.

Simon de Beauvoir (1953) unveils the relationship of inequality based on power between men and women. She characterizes men as powerful since they oppress women in every aspect of life. Women are considered as negative and dependent while men as positive, neutral, and independent (Beauvoir, p. 15). Women are depicted as inferior beings and "subordinated to men" (p. 18) in literature. Women in male-dominated societies are marginalized. They do not makeup one community with men; they live in differences "They live dispersed among the males" (p. 18). Women in such societies have a weak position. The patriarchal system becomes a legal weapon that can be easily used against women. Such societies restrict the life of women to their home and are not given the right to raise their voice in society. In such a patriarchal society, power lies in the hands of a male who is head of the family, "woman has always been man's dependant" (Beauvoir, 1953, p. 19). Rejection, frustration, and inequity become the fate of women in such a male-dominated society. Luce Irigaray and Julia Kristevia are also of the view that "the category of feminine identity is a social construct" (Morton, 2003, p. 74).

Western feminism has articulated miseries of the marginalized women by universalizing their Eurocentric values, "there must be a universal basis for feminism" (Butler, 1999, p. 6). Western feminism has attempted to represent women of third-world countries and consequently, non-Western women have remained voiceless. Women indeed suffer in male-dominated societies but the miseries of women depend on their cultural specifics. Western feminists have universalized Eurocentric views.

* Department of English, University of Haripur, Haripur Khyber Pakhtunkhwa, Pakistan

** Department of English, University of Malakand, Chakdara Khyber Pakhtunkhwa, Pakistan

*** Department of English, University of Malakand, Chakdara Khyber Pakhtunkhwa, Pakistan 
However, their claim of universal sisterhood has been challenged by Chandra Talpade Mohanty and Gayatri Chakravorty Spivak who emphasize cultural differences in the study of feminist issues (Morton, 2003, p. 78). According to Mohanty (1991), Western feminism is based on "ethnocentric universality" (p. 53).

This paper addresses the issue of gender bias in the novel of Khaled Hosseini, A Thousand Splendid Suns. The views of Chandra Talpade Mohanty are relevant in this context since the novel depicts the oppression of Afghan women whose cultural life is different from Western culture. It is better to study male violence by considering the cultural background of Afghanistan. The female characters in the novel are treated as inferior creatures and are dependent on male relatives. The novel depicts the miserable life of Afghan women in a Pashtun society where a male remains dominant. It portrays a patriarchal Pashtun society where a man has to be mentally and physically strong to protect his family. Only such a male has respect and prestige in society.

\section{Literature Review}

A Thousand Splendid Suns portray the issues of male chauvinism, ethnic differences, tyrannical reign of the Taliban, women's education, and the tragic fate of an illegitimate child (harami) in Afghanistan. The novel has been analyzed through the lens of feminism in various research articles. Binod Sapkota (2020) appreciates the novel by analyzing the characters of Mariam and Laila who fight against patriarchal power. On the tolerance of women (Mariam and Laila) in Afghanistan, Bindu Ann Philip (2016) comments that women in Afghanistan have to endure injustices due to gender inequality. The article highlights social and political injustices inflicted upon women in Afghanistan. It also analyses Orientalist representation of Afghan men.

Priyanka Chaudhary (2020) analyses the concept of Othering in the novel A Thousand Splendid Suns. The article includes Karl Marx, Edward Said, Gayatri Spivak, and Foucauldian's theory of power relation. Chaudhary (2020) highlights the marginalized and objectified status of women who are dependent on their male relatives (p. 1469).

Rebecca A. Stuhr (2011) also analyses the characters of Mariam and Laila who challenge the patriarchal power in Afghan society. Unlike Afghan women, Mariam and Laila are active in showing resistance to male chauvinism. The author highlights the brutal nature of a Pashtun character, Rasheed, who is the husband of Mariam and Laila (p. 55). Stuhr (2011) highlights the agonies of Mariam and Laila who support each other to fight against the ruthlessness of their husbands.

Lindsay B. Shapiro (2010) focuses on thematic similarities between the miserable status of the Middle Eastern women covered in The New York Times and Afghan women depicted in $A$ Thousand Splendid Suns. It examines the female characters of Mariam and Laila who develop a bond of unwavering friendship to resist the tyranny of the male-dominated society. Shapiro (2010) highlights the brutal nature of Rasheed, Pashtun, who is the husband of Mariam and Laila. Mariam and Laila are forced to wear a burqa (veil) and are not allowed to move out of their house without their husband's permission. The study also analyses the insecure position of Afghan women who are expected to produce male children. Middle Eastern women face the same problems. The issues of childbearing, sexual abuse and a low ratio of women education are covered by The New York Times.

The various research works, mentioned above, focus on the marginalized position of Afghan women. They aim to compare Afghan women with Western women which creates confusion. They have not considered the role of cultural context since Afghanistan is a Muslim country that has people of various ethnic groups. People of the Pashtun ethnic group take more inspiration from their cultural law called Pashtunwali. Therefore, understanding Afghan culture plays an important role in the feminist study of A Thousand Splendid Suns.

\section{Methodology}

The research article is based on qualitative research which follows an inductive approach. Inductivism is a data-driven approach (Seliger \& Shohamy, 1995, p. 31). The relevant passages are selected from the novel, A Thousand Splendid Suns, and analyzed in the light of Mohanty's (1991) views. The analysis includes interpretation of the selected passages.

\section{Women in Afghan Society}

Khaled Hosseini (2008) in the novel portrays the subjugation of Afghan women since the society has a patriarchal system in which women do not have an active role to play. Moghadam attempts to analyze patriarchy in Afghanistan and points out various forms of patriarchal authority in 
Afghanistan; men and women are segregated in this society; men are bound to protect the honor of their women (as cited in Kazemiyan 2012, p. 18).

The novel narrates the story of the miserable life and sacrifices of two female characters, Mariam and Laila, in Afghanistan. It narrates the story from the time of the Soviet's invasion of Afghanistan in the 1970s to the emergence of the Taliban in the 1990s. The two females struggle against the stronghold of men who keep them suppressed. Tilwani (2013) is of the view that in Afghan society women, such as Mariam and her mother Nana, suffer due to patriarchy which gives a powerful status to men (pp. 119-120). Men are secure in such a society no matter what they do, but for women, a slight violation and transgression can become a stigma for the whole of their life. This is the reason that Nana, Mariam's mother, does not deserve a respectable status in society because she gives birth to an illegitimate child, Mariam. Mariam is addressed as 'harami' an illegitimate child, "Mariam was five years old the first time she heard the word harami" (Hosseini, 2008, p. 3). Further, Nana says to Mariam, "You are a clumsy little harami. This is my reward for everything I've endured" (p. 4). The inferior status of such a child is further explained, "That a harami was an unwanted thing; that she, Mariam, was an illegitimate person who would never have a legitimate claim to the things other people had, things such as love, family, home, and acceptance" (p. 4).

Mohanty (1991) is of the view that victimization of women must be studied within "specific societies" (p. 58). In Afghan culture, an illegitimate child "harami" is not accepted, as Hosseini says "Nor was she old enough to appreciate the injustice, to see that it is the creators of the harami who are culpable, not the harami, whose only sin is being born" (Hosseini, 2008, p. 4). In such a society, a female suffers for giving birth to an illegitimate child i.e. she is not married to a man. The penalty is, therefore, inflicted upon the woman and her child.

The socio-cultural discrimination is fully grasped by Nana. She is well aware of the illegal status of her daughter. She knows that the patriarchal society will never spare her illegitimate child. Illegal children are not entitled to love, family, and acceptance. Only Nana, being a mother, gives protection to her illegitimate daughter, Mariam. She says about Mariam's position in the society that "There is nothing out there for her. Nothing but rejection and heartache" (Hosseini, 2008, p. 18). She makes the point clear to Mariam that people will humiliate her if she gets admission to a school as no one accepts her illegal status.

Nana's character shows cruelty inflicted upon women in a patriarchal society. Her status is reduced to the level of an animal. She is thrown away not only by Jalil, Mariam's father but also by her father. She gives up her struggle to resist a male social order and accepts her objectified status. She believes that women in a male circle cannot survive without endurance. Women have to endure all the brutality imposed upon them by their men. She teaches the same lesson to her daughter, Mariam, as well. She tells Mariam that "There is only one skill a woman like you and my need in life, and they don't teach it in school... And it's this: tahamul. Endure" (Hosseini, 2008, p. 17). However, Nana's victimization should not be studied within the framework of Western feminism; her case must be analyzed in the light of Afghan culture which does not allow the sexual relationship of men and women out of wedlock.

A woman is considered submissive and frail in a male chauvinistic society and for this reason, she is all the time blamed. A man can easily absolve himself from the sins and crimes but this is not possible for a woman. Nana says to her daughter Mariam, "Like a compass needle that points north, a man's accusing finger always finds a woman" (Hosseini, 2008, p. 7). Jalil loves Mariam but he does not keep her at home. He does not give her time the way he gives to the rest of his wives. Love and affection are forbidden for an illegitimate child; Jalil promises Mariam to take her to the cinema but never takes his words seriously. Nana warns Mariam that only a mother can bless her child with love and kindness; she tells her that Jalil is not kind and loving like Nana; it is Nana who takes care of Mariam because she has given birth to her (Hosseini, 2008, p. 27). After the suicide of Nana, Mariam gets married to a Pashtun shoemaker, Rasheed, from Kandahar who lives in Kabul. He is much older than Mariam. She is not willing for this marriage, but having no other option she has to go with him to Kabul where new miseries await her.

Afghanistan is a Muslim country. The country has people of various ethnic groups. Pashtun people constitute a major ethnic group in the country (Wahab \& Youngerman, 2007, p.14). The y follow their cultural law Pashtunwali which has more influence on the cultural life of Pashtun people. Therefore, it is wrong to believe that all Muslim women face the same problems. Mohanty has 
supported the same view that all Muslim women are expected to face some problems and thus their cultural differences are not discussed (Mohanty, 1991, p. 61). In a Pashtun society, a woman is considered as nang and namoos. Nang and namoos constitute the main feature of Pashtunwali which constitutes the cultural law of Pashtuns; it is a code of conduct of Pashtun people. According to Glatzer (1998), nang means "honor and shame" while namoos refer to the respectable status of women in Pashtun society (p. 5). It is a man's responsibility to defend and protect a female from the harm of society. The loss of a woman's honor and respectable status leads to humiliation not only of her man but also of the whole family. Therefore, the loss of nang and namoos is an unforgivable sin in Pashtun society.

It is due to nang and namoos that Rasheed's society cannot ignore the fault of a woman. A woman's mistake is an unforgivable act (especially in case of a moral violation), which in most cases leads to the killing of her. From this context, Rasheed warns Mariam by saying that he will not hesitate in killing her if she violates nang and namoos (Hosseini 2008, p. 70). It is a husband's responsibility to protect his wife's honor. For a Pashtun man, the honor of his woman is more valuable in his society. This is the reason that Rasheed is meticulous about his wife. He warns Mariam to be very conscious about her "nang" and "namoos". He tells her that modern women visit his shop; they wear skirts and expose their knees and let strangers touch their bare feet. These women belong to the elite class who do not cover their faces and just distort the honor of a Pashtun man (Hosseini, 2008, p. 63). Rasheed being a Pashtun man considers the honor of women a sacred thing. He believes that women should cover up the ir whole bodies in front of the public. He is of the view that women should stay at home or be accompanied by a male relative while going outside their homes.

Likew ise, Rasheed gives the same moral lesson to Laila, "I am your husband now, and it falls on me to guard not only your honor but ours, yes, our nang and namoos. That is the husband's burden" (Hosseini 2008, p. 223). After getting married to Laila, Rasheed starts giving her the same instructions about "nang and namoos,". He makes the point clear to her that regarding the matter of women's honor and dignity, he cannot compromise. He is extremely careful about his wives' honor because, for him, loss of nang and namoos means loss of his respectable status in society.

Therefore, the plight of Afghan women should not be studied in the light of Western feminism just as most of the researchers do. Stuhr (2009) is one of them who points out the plight of Afghan women in the novel, A Thousand Splendid Suns, and is of the view that Hosseini (2008) has focused on the wretchedness of women in the novel (p. 61). Stuhr (2009) analyzes the status of women in Afghanistan in the following words, "Rasheed viewed her (Mariam) as a sexual tool. Her function was to conceive a 'son'. As soon as Rasheed realized that she was infertile, she was abandoned immediately" (pp. 6-7). Women's biological importance is considered men's eternal need as is portrayed in A Thousand Splendid Suns. Mariam is only a sexual tool for Rasheed. He desires and most of the time forces Mariam to conceive a male child. Tilwani (2013) says that women in this society are expected to give birth to boys only (p. 30). Therefore, when Rasheed realizes that Mariam gives birth to only dead baby girls, it turns him aggressive. He starts beating her and scolds her all the time for her infertility. This is considered another unforgivable sin in Mariam's personality from a male's perspective.

The birth of a male child is a great source of celebration in Afghan society. Rasheed wants a male child and expects only a boy from Mariam since he suggests the name of Zalmai for his future son. When Mariam asks him about the name of a girl, his response is cold and says "it is not, but, if it is a girl, then you can choose whatever name you want" (Hosseini 2008, p. 87). A drastic change in Rasheed's behavior occurs immediately after the death of the baby and he starts treating Mariam very harshly. He keeps himself away from her. Hosseini (2008) says about such a situation that Rasheed ignores Mariam especially after the death of the baby; she tries her best to please him but his cold response does not change (pp. 99-100). Mariam fulfills all his physical desires, cooks for him, and cleans the house to please him. However, all her efforts go in vain. She could have won the sympathy of Rasheed only after giving birth to a boy but she fails seven times in it which makes her wretched. She becomes only a burden for Rasheed and it is visible through his terrible and aggressive looks.

In Pashtun society, a man needs men to protect his family. More men in a family lead to a strong position. This is the reason that the birth of Zalmai from Laila makes Rasheed happy. He shifts him to his room and buys new clothes, diapers, and new bottles for him, though he cannot afford them. After the birth of his daughter, Aziza from Laila, he buys a few toys for her at Laila's request. 
His likeness for Zalmai has no bounds (Hosseini 2008, p. 296). He does not show love and affection to his daughter, Aziza.

Rasheed's harsh treatment of his wives gets worsened. The provision of even a male child does not lessen his aggressiveness and brutality toward his wives. Eventually, the violence becomes intolerable for both of his wives and they desire to get rid of his inhuman behavior. Mariam and Liala make a plan to run away from Rasheed but get arrested and are taken back to Rasheed. He does not utter a word and starts penalizing Mariam ruthlessly (Hosseini, 2008, p. 268). In Pashtun society, running away from a woman from her husband's home is considered a crime. Strict laws are implemented which keep women bound by not allowing them to travel without a male escort. The act of Mariam and Laila is intolerable for Rasheed. He first beats Mariam brutally and then starts beating Laila. While beating Laila mercilessly, Mariam interrupts in saving Laila by killing Rasheed. Afterward, Mariam is arrested by the Taliban for killing Rasheed. During the trial, a young Talib tells Mariam that men are gifted with higher intellectual levels than women (Hosseini 2008, p. 365).

Mariam offers herself sacrifice since she wants to save Laila and her children. She closes the chapter of her life tragically and remains in prison. Eventually, she has sentenced to the death penalty for killing her husband. Mariam and Laila deve lop a strong bond re lationship based on trust and love. Stuhr (2009) says in this regard that the novel depicts two different female characters i.e. Mariam and Laila; the two female characters are different from each other and are raised in different societies of Afghanistan; despite having different temperaments, they develop a strong bond of friendship at the end of the story (p. 60). Though they get married to Rasheed against their will, they make their life happy. This is the reason Hosseini (2008) says that "[Mariam] was leaving the world as a woman who had loved and been loved back. She was leaving it as a friend, a companion, a guardian, a mother. A person of consequence at last" (p. 329). Mariam resists against male-chauvinism in Afghan society. She makes sacrifices for Laila and her children and lets herself be executed for the murder of Rasheed. She feels happy to resist against male-domination eventually. She remains alive in Laila's heart (Hosseini 2008, p. 414).

\section{Conclusion}

The study analyses the marginalized status of women in Afghan society where Pashtun people live under Pashtunwali. Women in Afghanistan face problems that are different from those highlighted by Western feminists. Illicit sexual relationship spoils the life of women in Afghan society since sexual relationship out of wedlock is strictly prohibited in Afghan culture. Therefore, illegitimate children are never accepted in this society. Women in Pashtun society constitute nang and namoos. It is a man's responsibility to protect nang and namoos. The loss of nang and namoos not only humiliates the man and his family but also puts the women in a miserable situation. To protect the honor of women, a man in Pashtun society exercises an authoritative status. Hosseini (2008) criticizes Pashtun society which is male chauvinistic. His novel depicts the resistance of women against the dominance of the male community. According to him, women in Afghan society are deprived of powerful positions since they are considered weak. He is more under influence of Western feminism.

\section{References}

Aihong, R. (2012). "Women characters in Katherine Mansfield's short stories." Studies in Literature and Language, 5(3), 101-07.

Bernt, G. (1998). "Being Pashtun - being Muslim: Concepts of person and war in Afghanistan in Glatzer." Essays on South Asian Society: Culture and Politics 2, Berlin: Das Arabische Buch, 4, http://www.khyber.org/publications/021-025/glatzer1998.pdf

Beauvoir, S. D. (1953). The second sex. (H. M. Parshley, Trans.). Jonathan Cape.

Boose, L. E. (1991). "Scolding brides and bridling scolds: Taming the woman's unruly member." Shakespeare Quarterly 42(2), 179-213. Published by George Washington University. http://www.jstor.org/stable/2870547

Butler, J. (1999). Gender trouble: Feminism and the subversion of identity. Routledge.

Chattopadhyay, A. (2011). "Women in Victorian society as depicted in Thomas Hardy's novels." International Journal of Educational Planning \& Administration, 1(01), 23-28. http://www.ripublication.com/ijepa.htm.

Chaudhary, P. (2020). "Layers of discourse and gender relation in Khaled Hosseini's A thousand splendid suns." Humanities and Social Sciences Review, 8(03), 1464-1471. 
Gerlach, J., Almasy, R., \& Daniel, R. (1996). Revisiting Shakespeare and gender. WILLA. (5), 179213.

Hosseini, K. (2008). A thousand splendid suns. Penguin Group.

Kazemiyan, A. (2012). A thousand splendid suns: Rhetorical vision of Afghan women. Department of Communication, University of Ottawa.

Khattak, R. W. S., Mohammad, F., \& Lee, R. (n. d.) "The Pashtun code of honor." Research Journal of Area Study Centre, University of Peshawar-Pakistan. http://www. Asc-centralasia. edu. Pk/Issue_65/01_The\% 20Pashtun_Code_of_Honour.html.

Keshavarzi, A. (2012). "ISAs and their function in Thomas Hardy's novels". International Journal of Social Sciences \& Education, 2(3).

Shapiro, L. B. (2010). Middle Eastern women's issues: An analysis of A thousand splendid suns and The New York Times. [Master's thesis]. http://etd.fcla.edu/UF/UFE0042591/shapiro_l.pdf

Mohanty, C. T. (1991). Under Western eyes: Feminist scholarship and colonial discourses. In C.T. Mohanty., A. Russo., L. Torres (Eds.), Third World feminism and the politics of feminism (pp. 51-80). Indiana University Press.

Morton, S. (2003). Gayatri Chakravorty Spivak. Routledge.

Philip, B. A. (2016). "Endless endurance: A feminist study of Khaled Hossieni's novel A thousand splendid suns." International Journal of Applied Research 2016, 2(5), 791-801.

Sapkota, B. (2020). "Ideological essentialisation of Afghan women in Hosseini's A thousand splendid suns." THE BATUK: A Peer-Reviewed Journal of Interdisciplinary Studies, 6(1), 55-62.

Seliger, H. B., \& Shohamy, E. (1995). Second language research methods. Oxford University Press.

Stuhr, R. (2009). Reading Khaled Hosseini. Greenwood Press.

Stuhr, R. A. (2011). "A thousand splendid suns: Sanctuary and resistance." Retrieved from https://repository.upenn.edu/cgi/viewcontent.cgi?article=1091\&context=library_papers

Stabile, C. A. (2005). "Unveiling imperialism: Media, gender, and the war on Afghanistan." Media, Culture \& Society 27(5), 765-82.

Sultana, A. (2011). Patriarchy and women's subordination: A theoretical analysis. file:///C :/Users/Hp/ Downloads/12929-Article\%20Text-47213-1-10-20121213.pdf

Tilwani, S. A. (2013). "Subalternity: A question in Amitav Ghosh and Khaled Hosseini." Third Front, Journal of Humanities and Social Science, 1(1). http://www.thirdfront.in/.

Tyson, L. (2006). Critical theory today. Routledge.

Wahab, S., \& Barry, Y. (2007). A brief history of Afghanistan. Infobase Publishing. 